\title{
The Impact of HVDC Links on Transmission System Collapse
}

\author{
Hualei Wang*1, Hanjing Zhang ${ }^{2}$, Chengqing Song ${ }^{3}$, Chao $\mathrm{Xu}^{4}$ \\ State Grid Shandong Electric Power Corporation Qingdao Power Supply Company No. 69. Liao Ning Road, Qingdao, \\ China
}

\begin{tabular}{ll}
\hline \hline Article Info & ABSTRACT \\
\cline { 2 - 3 } Article history: & $\begin{array}{l}\text { Modern power systems are continually being expanded, are required to carry } \\
\text { more power and are being increasingly interconnected. All of these increase } \\
\text { the risk of wide area blackout.In 2003 the North America Blackout } \\
\text { Received Nov 14, } 2017 \\
\text { Revised Dec 1, 2017 } \\
\text { Accepted Jan 3, 2018 }\end{array}$ \\
$\begin{array}{l}\text { collapse propagating through a network. The HVDC link between Quebec } \\
\text { and New York ensured that the system collapse did not progress beyond the }\end{array}$ \\
$\begin{array}{l}\text { HVDC interconnection interface. The objectives of this paper are to } \\
\text { investigate contributions that integrate HVDC interconnections into AC } \\
\text { networks. The simulation studies were performed using MATLAB. }\end{array}$
\end{tabular}

Corresponding Author:

Hualei Wang,

State Grid Shandong Electric Power Corporation,

Qingdao Power Supply Company,

No. 69 . Liao Ning Road, Qingdao, China.

Email: gavinwangwei@163.com

\section{INTRODUCTION}

The HVDC transmission technologies are playing more important roles in world's power transmission systems. The use of HVDC technologies can contribute to satisfying these demands. HVDC technologies provide immediate benefits to power grid including bulk power delivery, long distance transmission and asynchronous interconnections.

The 2003 Northeast America blackout suggested that HVDC interconnection provide a 'firewall' against system collapse spreading through the networks. This was seen during the Northeast blackout in the USA on 14th August 2003 [1,2] where around 50 million people were affected by the loss of 61,800MW of load. The commercial losses have been estimated at between $\$ 4$ billion to $\$ 10$ billion [4]. The HVDC link between Ontario and New York ensured that the system collapse did not progress beyond the interconnection interface when outage propagated through Qntario and New York [3].

This paper investigates the impact of HVDC constraining system collapse transmitting through the power networks and the influence that HVDC links bring to distance relays. The paper also examined what could happen if the interconnection had been HVAC. In order to investigate certain impact, the 2003 Northeast U.S.A. and Canada blackout will be simulated using MATLAB. A similar power system but interconnected by HVAC line will be modeled for comparison.

\subsection{North America Blackout}

On 14th August 2003, Northeast U.S.A suffered from the worst outage event in history [4-16]. The blackout led to about 61,800-MW power lost and affected about 50 million people in Ontario and the eight states in U.S. Northeast. During the event, over 400 transmission lines and 531 generating units at 261 power plants tripped. The outage was inferred by failure of two $345-\mathrm{kV}$ transmission line due to tree contact [4]. The events started slowly, but spread quickly and finally caused widespread voltage collapse in both Canada 
and Northeast United States. The U.S.-Canada Power System Outage Task Force final report [9] gave four causes for the blackout: inadequate system understanding, inadequate situational awareness, inadequate tree trimming and inadequate RL diagnostic support. Figure 1 shows the affected area during blackout [10].

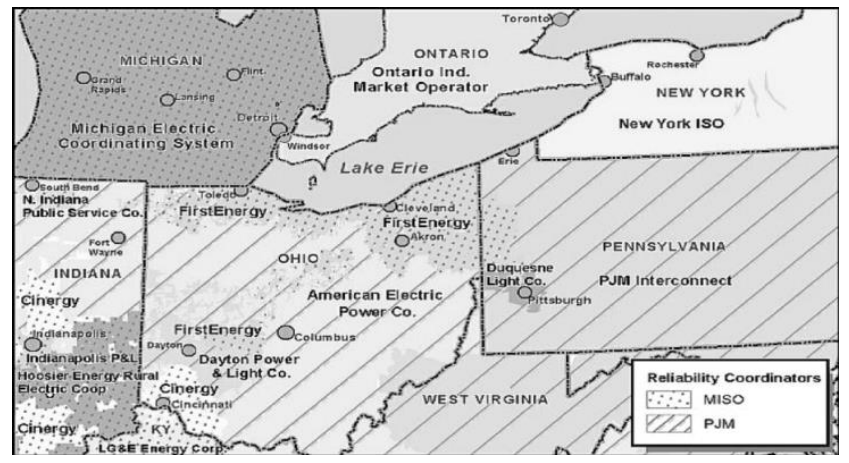

Figure 1. Affected area during blackout [10]

The evidence indicates that distance relays tripping caused the loss of many key lines and accelerated the spread of the cascade. These distance relays responded to overloads rather than faults on the protected facilities [17-22]. Between 16:05-16:10 many 345-kV lines tripped on Zone 3 relays [9, 17-22]. Sammis-Star 345-kV line tripped on relay operation at 16:06:03. Galilon-Ohio Central-Muskingum 345-kV line tripped on Zone 3 relay and reclosed at 16:08:58. The line tripped finally at Galilon on a ground fault. East Lima-Fostoria Central $345-\mathrm{kV}$ line tripped on Zone 3 relay at 16:09:06. Tripped lines led to some generation units become overloaded and tripped as well between 16:09 and 16:10. New York-New England transmission lines disconnected at 16:10:46.

According to ref [9], there were three principal reasons that caused the cascade spread beyond Ohio and caused such a widespread blackout. First, the loss of the Sammis-Star 345-kV line in Ohio led to other transmission lines tripped. Second, many of the key lines were tripped out by the operation of Zone 3 impedance relays. Relays responded to overloads situations rather than true line faults. These relays' operations accelerated the spread of the cascaded. Third, the relay protection settings may not be entirely appropriate. Relays did not operate as expected during the cascade. Figure 2 shows the apparent impedance inside Zone 3 of the distance protection on the $345 \mathrm{kV}$ transmission line between Sammis and Star [17-22].

However, as a key part of east interconnection, Quebec was not affected by the outage. It is reported that Quebec is connected only by DC ties [8]. During the event, DC links acted as buffers that not allowed disturbance propagate through. Lots of papers have pointed out that HVDC links acted as a stability booster and 'firewall' against disturbance during 2003 USA-Canada blackout [5, 11, 14, 23-35].

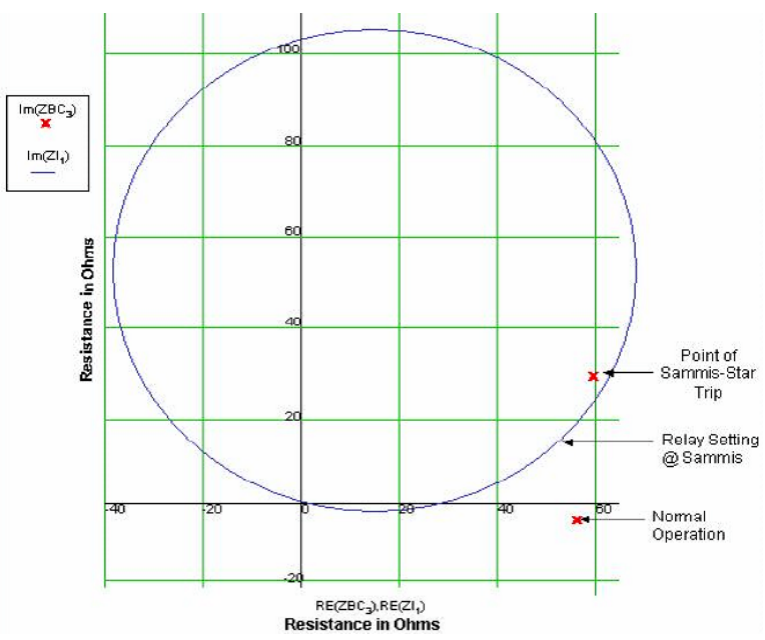

Figure 2. Zone 3 distance relay operation on the 345-kV Sammis-Star transmission line [17-22]

IJEEI, Vol. 6, No. 1, March 2018: $21-31$ 


\section{HVDC INTERCONNECTIONS TO PREVENT VOLTAGE OUTAGE}

HVDC interconnection can help to prevent cascading outage pass through and enhance power systems. Carlsson [23, 35] reported that HVDC has good controllability of transmitted power. When using HVDC, the power direction can be changed rapidly in a second. With the ability to change the operating point instantaneously so that HVDC can feed/reduce active power into the disturbed system to control the frequency much faster than a normally controlled generator [37]. Carlsson [25, 36] said classical HVDC transmission can vary the power level from minimum load, which normally between $5 \%$ and $10 \%$, to max load $100 \%$. He suggested that the DC interconnection could be made to automatically adapt its power flow during outage. The power flow can be limited to protect the network. He also claimed that HVDC can help to reduce voltage oscillations by connecting capacitors or by modulating the station's reactive power consumption by firing angle control. HVDC transmission link has good performance under connected AC system faults. Such specific actions, like normal power control, emergency power control and voltage control, can help during contingencies. The most important feature of HVDC is that it can never become overloaded [36, 38]. Pan et al [24] claimed that by fast power run-up or run-back control functions, HVDC can help maintain power grid stability. With the ability to control both active power and reactive power, HVDC can provide an effective means of damping oscillations and improve voltage stability. According to [39], when one of the systems has oscillation mode between two generator groups, HVDC has the best active power damping effect if the converter station is electrically close to one of the oscillating generator group. The best location for reactive power damping is the electrical middle point between the oscillating generator groups [39]. HVDC system is provided with power modulation features for stabilization of AC system [37]. With this function, HVDC link can reduce power swing and stabilize the entire system in minimal time.

After the 2003 northeast blackout the North American Electric Reliability Council in its technical report suggested that use HVDC transmission system to improve power networks' reliability and enhance power systems [15]. Lots of papers [11-33] also suggested the same as well as ABB and Siemens. Loehr [37] has been advocating the breaking up of the two gigantic interconnections or grids that straddle North America into a number of smaller ones since 1999. In his suggestion, these mini-grids can be interconnected by HVDC instead of current AC ties. As Loehr explained, "With ac ties, what happens in one place on the grid affects everywhere else. A major disturbance in Ontario is felt as far away as Oklahoma, Florida and Maine. This doesn't happen with DC links - it insulates one small grid from the others, but still permits power exchange."

Nowadays, lots of researchers are investigating the HVDC functions as firewall against oscillations since it was proved in 2003 northeast American blackout. Hafner and Manchen in [14] used the Caprivi Link Interconnector HVDC Light project to study the strong voltage and frequency stabilization function of HVDC function to avoid blackout. By several actual commissioning tests, they showed that HVDC link had good performance under islanded AC networks and normal AC faults. They suggested that HVDC system is able to enhance the stability of extremely weak AC system and to prevent the blackout. [40] examined enhance power system stability through controlling HVDC power flow. In paper [38], Ozerdem and Habboob used MATLAB simulated Turkey to TRNC HVDC submarine interconnection. By comparing VSC-based HVDC and CSC-based HVDC performance under the same applied AC fault, they found that VSC-based HVDC had a better performance than CSC-based HVDC. In 1993 Lee et al [41] suggested to use potential DC system support to enhance AC system in western U.S. Corsi et al [42] discussed the Sardinia-CorsicaItaly HVDC link (SACOI) and the Italy-Greece HVDC link (GRITA) by simulation tests and commissioning results. They demonstrated that using HVDC power modulation can achieve high control flexibility and regulation performance, which are contributing to face unexpected contingencies. Arro and Silavwe [43] discussed what influence a line-to-ground fault occurring on HVDC line will bring to involving AC lines. In order to study the phenomenon, a simulation studies were carried on by PSCAD/EMTDC. A bipolar HVDC connection between the Swedish and Finnish power systems was simulated. Based on simulation work in [43], there was no unwanted tripping in AC lines due to a line-to-ground fault occurred on HVDC lines. Paulinder [44] claimed that an HVDC link has an obvious contribution to power system's stability during disturbance through modeling CIGRE Nordic 32 system. Du in [45] investigated the VSC-based HVDC control system's operations under steady-state and different fault conditions. The HVDC link was used different control strategies. Faults were injected at inverter side and converter side separately. It was conclude that for unbalanced faults the voltage dips in the dc-supplied ac system are less severe than in the pure ac system.

HVDC and Flexible AC Transmission Systems (FACTS) were strongly advised in [30-35, 46-48]. As described in $[31,32]$ 'FACTS, based on power electronics, have been developed to improve the performance of weak AC Systems and for long distance AC transmission. FACTS controllers can, however, also contribute to solve technical problems in the interconnected power systems. FACTS are applicable in parallel connection, in series connection, or in combination of both to control load flow and to improve 
dynamic conditions. By these means, FACTS contributes to Blackout prevention too.' Therefore, developing large hybrid transmission systems, consisting of HVDC and FACTS, is necessary. Figure 3 gives a brief view of such hybrid AC/DC system. Such hybrid transmission system offers significant advantages in system reliability [32-35]. Performance of AC lines can be improved by FACTS both in transmission capability and reliability. Long-distance bulk power can be transmitted by HVDC. With DC interconnections, high system security could be achieved.

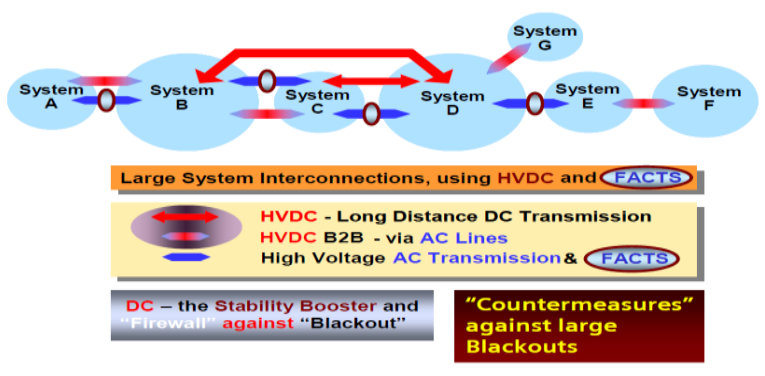

Figure 3. Hybrid AC/DC system [29-32]

\section{DISTANCE RELAY}

When fault occurs on a transmission line, the distance relay will protect the line, trip the circuit breaker and disconnect the line from the network [49]. By comparing the measuring impedance with the setting impedance to determine if the fault is inside or outside. If the measured impedance is less than the setting impedance, relay assumes a fault exists inside the protection zone and releases a trip logical signal [50]. Relay is located at the point R. The primary fault current, IF, is transferred to equivalent secondary fault current, $\mathrm{iF}$, via current transformer to the relay. The fault voltage VF is equivalent to the fault current IF product with fault impedance ZF. The secondary fault voltage is achieved by voltage transformer VT [51, 52]. Relay compares the measured impedance, $\mathrm{ZM}$, which is the division of secondary $\mathrm{V}$ and I to detect the fault.

$$
\begin{aligned}
& Z_{F}=\left(\frac{V}{\text { VTratio }}\right) /\left(\frac{I}{\text { CTratio }}\right) \\
& Z_{m}=Z_{F} *\left(\frac{\text { CTratio }}{\text { VTratio }}\right)
\end{aligned}
$$

A typical distance relay has three protected zones: zone 1, zone 2 and zone 3 . Zone 1 is always set up to $80 \%$ of the protected line impedance. Zone 2 should be at least $120 \%$ of the protected line impedance or the protected feeder plus $50 \%$ of the shortest following line impedance. Zone 3 is set up to the protected feeder plus the longest following feeder plus $25 \%$ of the shortest subsequent feeder or $120 \%$ of the protected feeder plus the longest following feeder. Some relays may have up to five protecting zones, some set to measure in the reverse direction [50]. Figure 4 shows a typical 3-zones distance protection

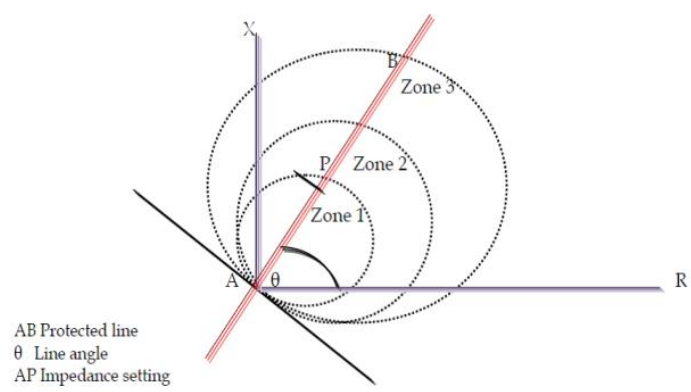

Figure 4. 3-zones of distance protection 
By comparing the measured impedance with the setting impedance the relay determines if the fault is inside or outside the protected zone [49]. Different fault types have different calculations of the fault impedance. References $[49,53]$ give the all fault-type calculation formulas.

$$
\begin{aligned}
& \text { A-N: } U_{A}=\left(I_{a}+k * 3 I_{0}\right) z_{1} l \\
& \text { B-N: } U_{B}=\left(I_{b}+k * 3 I_{0}\right) z_{1} l \\
& \text { C-N: } U_{C}=\left(I_{c}+k * 3 I_{0}\right) z_{1} l \\
& \text { A-B: } U_{A}-U_{B}=\left(I_{a}-I_{b}\right) z_{1} l \\
& \text { B-C: } U_{B}-U_{C}=\left(I_{b}-I_{c}\right) z_{1} l \\
& \text { C-A: } U_{C}-U_{A}=\left(I_{c}-I_{a}\right) z_{1} l
\end{aligned}
$$

where:

$U_{A}, U_{B}, U_{C}$ are a, b, c phase voltage;

$I_{a}, I_{b}, I_{c}$ are a, b, c phase current;

$I_{0}$ is the zero-sequence current;

$z_{1}$ is the positive sequence impedance of the protected line;

1 is the length of protected line;

$\mathrm{k}$ is the zero-sequence comparison factor, which could be described as:

$k=\frac{Z_{0}-Z_{1}}{3 * Z_{1}}$

where: $z_{0}$ is the zero-sequence impedance of the protectedline.

A full scheme distance relay was modeled as shown in Figure 5.

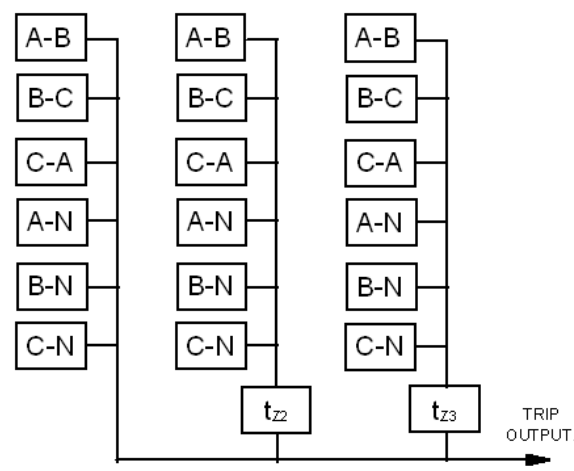

Zone 1 Zone 2

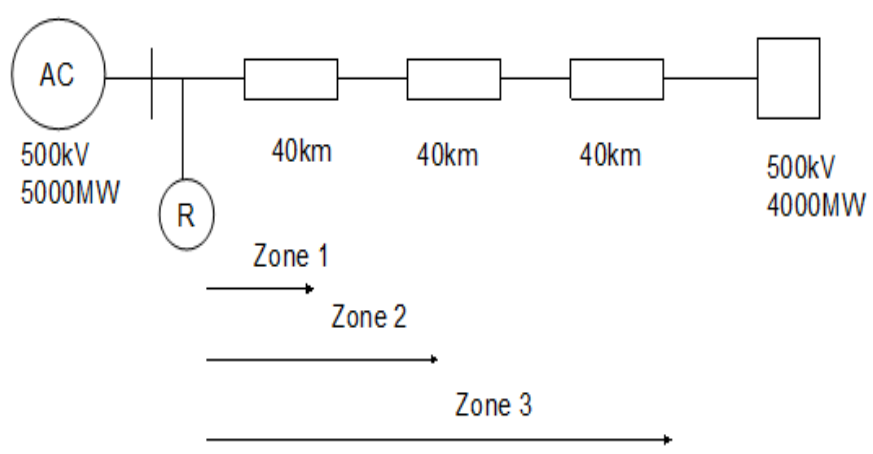

Figure 5. Full scheme distance relay

Figure 6. Simple transmission system

Zone 2 and Zone 3 timer was set to $200 \mathrm{~ms}$ and $500 \mathrm{~ms}$ respectively. The comparing circuits were achieved by block-average comparator ${ }^{1}$. The modelled distance relay was tested in a simple transmission system as shown in Figure6. A 500kV, 5000MW AC network transmitted power to a 500kV, 4000MW load through $340-\mathrm{km}$ transmission lines. The relay located to protect first $40-\mathrm{km}$ line. Zone 1 was set to $80 \%$ of the protected line. Zone 2 was set to $120 \%$ of the protected line. Zone 3 was set to protect whole line. 
Relay settings were shown in Table 1.

Table 1. Relay Settings

\begin{tabular}{cc}
\hline VT Ratio & $500 \mathrm{kv} / 110$ \\
CT Ratio & $2000 / 1$ \\
Zone 1 Reach & $32 \mathrm{~km}$ \\
Zone 2 Reach & $48 \mathrm{~km}$ \\
Zone 3 Reach & $120 \mathrm{~km}$ \\
\hline
\end{tabular}

Line parameters were given in Table 2.

Table 2. Line parameters

\begin{tabular}{cc}
\hline Line Length & $500 \mathrm{kv} / 110$ \\
Line Impedance & $0.079+\mathrm{j} 0.33 \Omega / \mathrm{km}$ \\
Line Angle & $76.5^{\circ}$ \\
\hline
\end{tabular}

A a-to-ground fault was injected into system at $20 \mathrm{~km}, 25 \mathrm{~km}, 30 \mathrm{~km}, 38 \mathrm{~km}, 40 \mathrm{~km}, 45 \mathrm{~km}, 49 \mathrm{~km}$, $50 \mathrm{~km}, 70 \mathrm{~km}, 100 \mathrm{~km}, 110 \mathrm{~km}, 120 \mathrm{~km}$ and $122 \mathrm{~km}$ respectively. Fault duration was $0.3 \mathrm{~s}-0.9 \mathrm{~s}$. Relay response was shown in Figure 7.

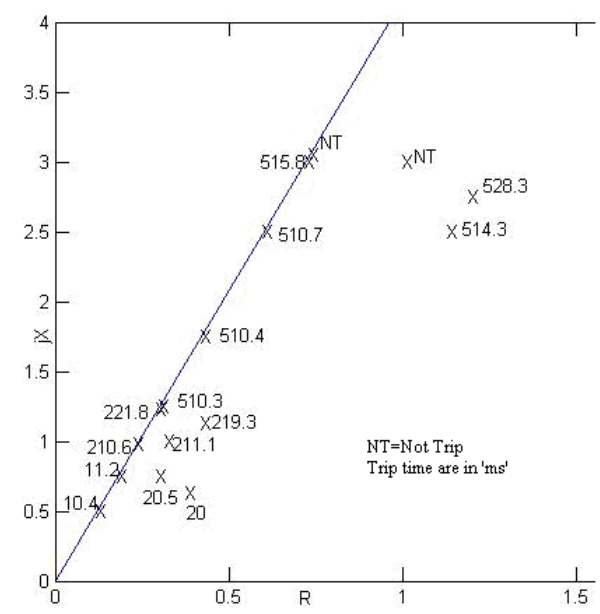

Figure 7. Trip time responses

\section{HVDC INTERCONNECTION}

In order to investigate distance relay operations during 2003 North America blackout, the HydroQuebec HVDC link was simulated using MATLAB based on a HVDC demo in MATLAB [54]. The HVDC transmission system was introduced by $\mathrm{ABB}$ in $[55,56]$ as well as in [57-59]. The transmission system connects hydro power station in James Bay area and load centres in Montreal and Boston. Main data was shown in Table.3 [55].

Table 3. Main data of Hydro-Quebec HVDC link [45]

\begin{tabular}{cc}
\hline Commissioning year & $1990-1992$ \\
Power rating & $2000 \mathrm{MW}$ \\
No. of poles & 2 \\
AC voltage & $315 \mathrm{kV}$ (Radisson), 230kV (Nicolet), 345kV (Sandy Pond) \\
DC voltage & $\pm 450 \mathrm{kV}$ \\
Length of overhead DC line & $1480 \mathrm{~km}$ \\
Main reason for choosing HVDC & Long distance, asynchronous networks \\
\hline
\end{tabular}

IJEEI, Vol. 6, No. 1, March 2018: $21-31$ 
The steady-state of the HVDC voltage at rectifier side and the HVDC voltage under a-to-ground fault at inverter side was shown in Figure 8.
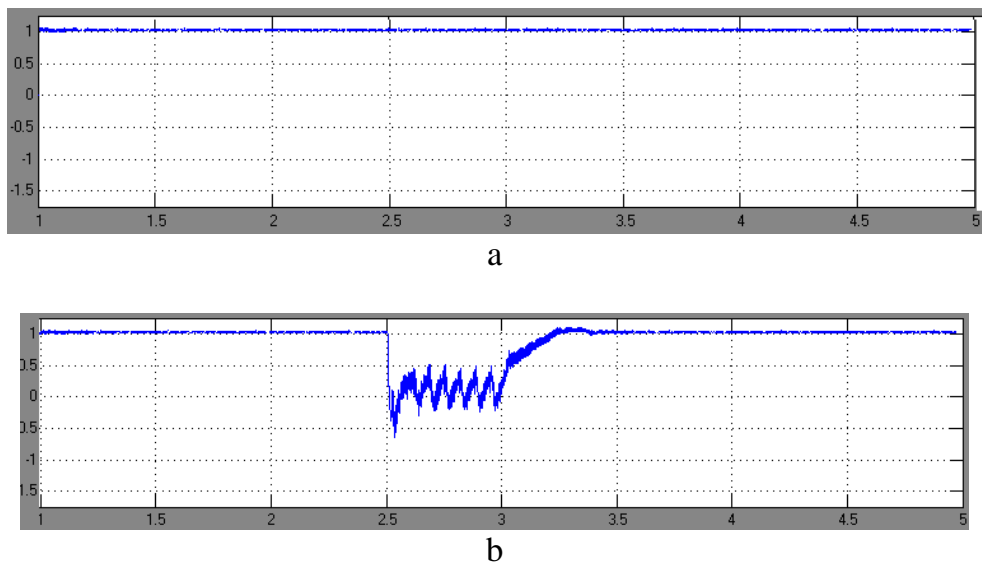

Figure 8. HVDC voltage a) Steady-state HVDC voltage at rectifier side b) HVDC voltage under a-to-ground fault at inverter side

\section{SIMULATION OF 2003 NORTHEAST AMERICA BLACKOUT}

The modelled power system in Figure 9 represents 2003 Northeast America blackout networks.

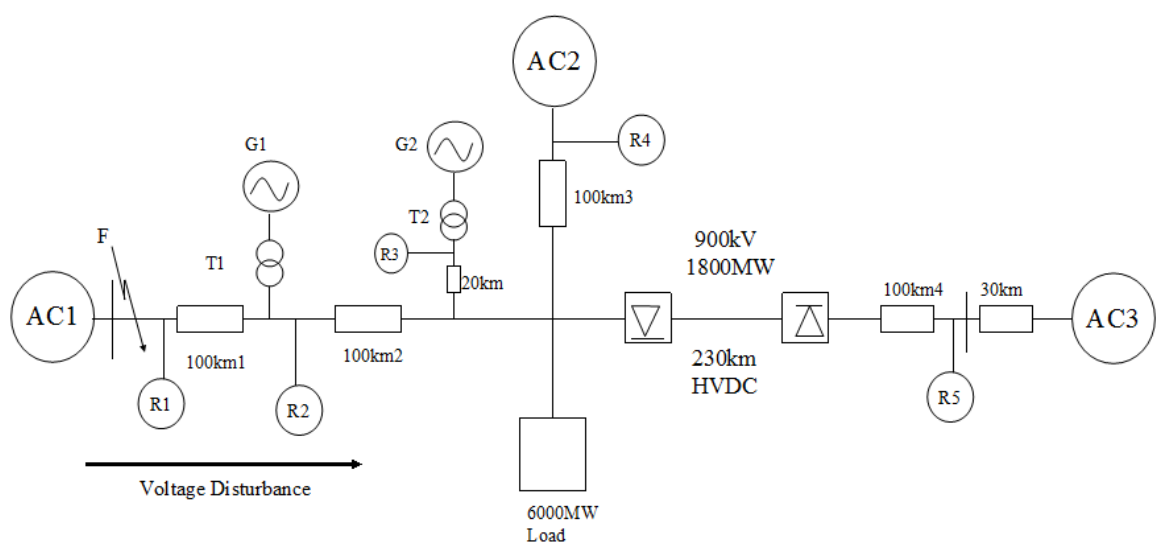

Figure 9. Modeled Power System

AC system 1 was $345 \mathrm{kV} 5600 \mathrm{MVA}$ equivalent power network, which represented East power networks. The system was performed by a $13.8 \mathrm{kV}, 5600 \mathrm{MW}$ synchronous generator and a $345 \mathrm{kV}, 4000 \mathrm{MW}$ load. AC system 2 was $345 \mathrm{kV}$ 10GVA equivalent power network which represented New England power network during the event. Ac system 3 was Quebec Hydro power stations, which is a 735kV, 7902MVA equivalent power network. The 6000MW load represents Western New York System. AC system 1 connects to load through two 100-km lines. Between AC 1 and load there were two generation units G1 and G2 connecting to transmission lines. G1 and G2 were performed by simplified synchronous machines with nominal power rated $3000 \mathrm{MW}$. T1 and T2 were $13.8 \mathrm{kv} / 345 \mathrm{kv}$ transformers. Relay 1 was set to protect $100 \mathrm{~km}$ line 1 . Relay 2 was set to protect $100 \mathrm{~km}$ line 2 . Relay 3 was set to protect $20 \mathrm{~km}$ line. Relay 4 was set to protect $100 \mathrm{~km}$ line 3 . Relay 5 was set to protect $100 \mathrm{~km}$ line 4 . Details were shown in Tables 4 and 5 below. 
Table 4. Line parameters $[61,62]$

\begin{tabular}{ccc}
\hline Line & Line Impedance & Line Angle \\
& & \\
\hline $100 \mathrm{~km} 1$ & $0.01915+\mathrm{j} 0.092$ & $78^{\circ}$ \\
$100 \mathrm{~km} 2$ & $0.01915+\mathrm{j} 0.092$ & $78^{\circ}$ \\
$100 \mathrm{~km} 3$ & $0.0766+\mathrm{j} 0.3679$ & $78^{\circ}$ \\
$100 \mathrm{~km} 4$ & $0.0208+\mathrm{j} 0.3387$ & $86^{\circ}$ \\
$20 \mathrm{~km}$ & $0.0766+\mathrm{j} 0.3679$ & $78^{\circ}$ \\
\hline
\end{tabular}

Table 5. Relay Settings

\begin{tabular}{cccc}
\hline Relay & Zone1 & Zone2 & Zone3 \\
& & & $300 \mathrm{~km}$ \\
R1 & $80 \mathrm{~km}$ & $120 \mathrm{~km}$ & $300 \mathrm{~km}$ \\
R2 & $80 \mathrm{~km}$ & $120 \mathrm{~km}$ & $120 \mathrm{~km}$ \\
R3 & $16 \mathrm{~km}$ & $24 \mathrm{~km}$ & $300 \mathrm{~km}$ \\
R4 & $80 \mathrm{~km}$ & $120 \mathrm{~km}$ & $430 \mathrm{~km}$ \\
R5 & $80 \mathrm{~km}$ & $120 \mathrm{~km}$ & \\
\hline
\end{tabular}

For comparison, a similar power network was modelled as well. The comparison network was set the same with modelled 2003 blackout system but interconnected by $230 \mathrm{~km}$ HVAC transmission line. The network was shown in Figure 10. T3 was a $735 \mathrm{kv} / 345 \mathrm{kv}, 1800 \mathrm{MW}$ transformer.

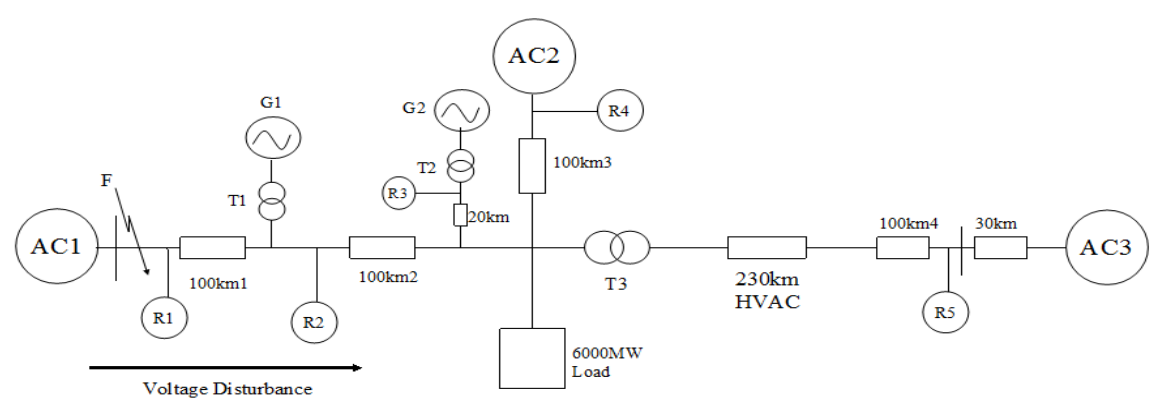

Figure 10. Comparison system

During 2003 Blackout, due to domino effect the first outage seen in Ohio finally affected New York system. At 1.2s, A-B-N fault was implied. Results were shown in Table.6.

Table 6. Simulation Results

\begin{tabular}{|c|c|c|}
\hline What happened during event & HVDC & $\overline{\text { HVAC }}$ \\
\hline $\begin{array}{c}\text { At 15:32:03 Hanna-Juniper } 345-\mathrm{kV} \text { line } \\
\text { tripped because of tree contact. The } \\
\text { tripped line cause following lines } \\
\text { overloaded. }\end{array}$ & $\begin{array}{l}\text { At } 1.2 \text { Phase-to-phase-to-ground fault was } \\
\text { implied into system. The } 100 \mathrm{~km} \text { line } 1 \text { was } \\
\text { tripped at } 1.23 \mathrm{~s} \text {. } \\
\text { Relay } 1 \text { Zone } 1 \mathrm{~A}-\mathrm{N} \text { tripped at } 1.23 \mathrm{~s} \text {. }\end{array}$ & $\begin{array}{l}\text { At } 1.2 \text { Phase-to-phase-to-ground fault was } \\
\text { implied into system. The } 100 \mathrm{~km} \text { line } 1 \text { was } \\
\text { tripped at } 1.24 \mathrm{~s} \text {. } \\
\text { Relay } 1 \text { Zone } 1 \mathrm{~A}-\mathrm{N} \text { tripped at } 1.24 \mathrm{~s} \text {. }\end{array}$ \\
\hline $\begin{array}{c}\text { 16:09:06 East Lima-Fostoria Central 345- } \\
\text { kV line tripped on Zone } 3 \text { relay. }\end{array}$ & $\begin{array}{c}\text { At } 2.27 \mathrm{~s} 100 \mathrm{~km} \text { line } 2 \text { was tripped. } \\
\text { Relay } 2 \text { Zone } 3 \text { A-B-N tripped at } 2.27 \mathrm{~s} \text {. }\end{array}$ & $\begin{array}{l}\text { At } 1.71 \mathrm{~s} 100 \mathrm{~km} \text { line } 2 \text { was tripped. } \\
\text { Relay } 2 \text { Zone } 3 \text { A-N tripped at } 1.71 \mathrm{~s} .\end{array}$ \\
\hline $\begin{array}{l}\text { During 16:09 to } 16: 10 \text { several power } \\
\text { plants tripped off the system. }\end{array}$ & $\begin{array}{c}\text { At } 2.27 \mathrm{~s} 100 \mathrm{~km} \text { line } 2 \text { was tripped. } \\
\text { Relay } 2 \text { Zone } 3 \text { A-B-N tripped at } 2.27 \mathrm{~s} \text {. }\end{array}$ & $\begin{array}{c}\text { At } 2.3 \mathrm{G} 2 \text { was tripped. } \\
\text { Relay } 3 \text { Zone } 3 \text { A-B-N tripped at } 2.3 \mathrm{~s} .\end{array}$ \\
\hline $\begin{array}{l}\text { New York-New England transmission } \\
\text { lines disconnected at 16:10:46 due to } \\
\text { apparent impedance. }\end{array}$ & $\begin{array}{l}\text { At } 3.35 \mathrm{~s} 100 \mathrm{~km} \text { line } 3 \text { was tripped. } \\
\text { Relay } 4 \text { Zone } 3 \text { A-N tripped at } 3.35 \mathrm{~s} \text {. }\end{array}$ & $\begin{array}{l}\text { At } 2.24 \mathrm{~s} 100 \mathrm{~km} \text { line } 3 \text { was tripped. } \\
\text { Relay } 4 \text { Zone } 3 \text { A-N tripped at } 2.24 \mathrm{~s} \text {. }\end{array}$ \\
\hline $\begin{array}{c}\text { HVDC tie with Quebec remained } \\
\text { connected to the western New York } \\
\text { system. }\end{array}$ & $\begin{array}{c}\text { The HVDC still connected to Load when } \\
\text { other AC transmission lines tripped. } \\
\text { Relay } 5 \text { did not trip. }\end{array}$ & $\begin{array}{l}\text { The HVAC line was tripped at 2.91s. } \\
\text { Relay } 5 \text { Zone } 3 \text { A-B-N tripped at } 2.91 \mathrm{~s} \text {. }\end{array}$ \\
\hline
\end{tabular}

IJEEI, Vol. 6, No. 1, March 2018: $21-31$ 
As can be seen from results, after fault occurred, at 1.23s R1 tripped $100 \mathrm{~km}$ line 1 which caused following 100km line 2 overloaded. R2 tripped line 2 at 2.27s due to Zone 3 protection. R3 tripped G2 at $2.81 \mathrm{~s}$ after line 1 and 2 were tripped due to overloaded current. $100 \mathrm{~km}$ line 3 was tripped by R4 due to apparent impedance. However, the HVDC transmission system remained transmitting power to load. R5 did not trip. Load was survived during blackout.

As a comparison, similar results were got from HVAC system. 100km line 1 was tripped at $1.24 \mathrm{~s}$ after fault occurred. Then the following $100 \mathrm{~km}$ line 2 tripped at $1.71 \mathrm{~s}$ due to R2 zone 3 protection. G2 and $100 \mathrm{~km}$ line 3 were tripped at $2.3 \mathrm{~s}$ and $2.24 \mathrm{~s}$ respectively. Unfortunately the HVAC line was tripped at $2.91 \mathrm{~s}$ due to R5 zone 3 protection. The load lost power completely during blackout.

\section{CONCLUSION}

In order to investigate the impact of HVDC links constraining voltage collapse propagating through the networks, the 2003 Northeast U.S.A and Canada blackout was simulated using MATLAB. The modelled system was compared to a similar system where they were connected using a HVAC line. The two systems were operated under the same situation including fault type and fault position. The performance of a distance protection on the near end line was examined using MATLAB. The results demonstrate how a HVDC interconnection can constrain system collapse propagating through a transmission system. Results also suggest that using HVDC interconnection is better than HVAC interconnection since HVDC can help to enhance power system stability during system collapse.

\section{REFERENCES}

[1] Wisconsin's Electrical System Response to the August 14,2003,Lake Erie Loop Cascading Electric System Outage Final Report [online]

[2] Loehr G.C., 2004. Is it Time to Cut the Ties that Bind? [online].

[3] Bahrman, M.P. AND Johnson B.K., 2007. The ABCs of HVDC Transmission Technologies. IEEE power \& energy magazine. pp. 32-44.

[4] Portante, E. C. K., J.A.; Folga, S.F.; Craig, B.A.; Talaber, L.E.; Wulfkuhle, G.R.; , (2010). Simulating the seismic performance of a large-scale electric network in the U.S. Midwest,. Simulation Conference (WSC), Proceedings of the 2010 Winter ,: pp.3482-3493.

[5] A RELIABLE TRANSMISSION SYSTEM.

[6] Bahrman, M. P. (2006). Overview Of Hvdc Transmission,. Power Systems Conference and Exposition, PSCE '06. 2006 IEEE PES pp.18-23,

[7] [Makarov, Y. V. R., V.I.; Stroev, V.A.; Voropai, N.I.; (2005). Blackouts in North America and Europe: Analysis and generalization,. Power Tech, 2005 IEEE Russia ,. Russia: pp.1-7,

[8] Farmer, R. G. A., E.H.; , (2006). Power System Dynamic Performance Advancement From History of North American Blackouts,. Power Systems Conference and Exposition, 2006. PSCE '06. 2006 IEEE PES , : pp.293-300

[9] U.S.-Canada Power System Outage Task Force (2004). Final Report on the August 14, 2003 Blackout in the United States and Canada: Causes and Recommendations.

[10] Andersson, G. D., P.; Farmer, R.; Hatziargyriou, N.; Kamwa, I.; Kundur, P.; Martins, N.; Paserba, J.; Pourbeik, P.; Sanchez-Gasca, J.; Schulz, R.; Stankovic, A.; Taylor, C.; Vittal, V.; , (2005). Causes of the 2003 major grid blackouts in North America and Europe, and recommended means to improve system dynamic performance,. Power Systems, IEEE Transactions on ,. vol.20, no.4,: pp. 1922- 1928,

[11] Gunther, B., Dusan,P., Dietmar,R., Erwin,T., (2005). Global Blackouts - Lessons Learned.

[12] Les, P. (2004). Similarities Between the 14 August 2003 Blackout and the Western System Collapses of 1996. IEEE power \& energy magazine: pp:54-57,.

[13] Apostolov, A. P. (2005). Distance relays operation during the August 2003 North American Blackout and methods for improvement,. Power Tech, 2005 IEEE Russia ,: pp.1-6,.

[14] Hafner, J. Y., Manchen,M., (2011). Stability Enhancement and Blackout Prevention by VSC Based HVDC. The electric power system of the future Integrating supergrids and microgrids International Symposiyum. Bologna, Italy.

[15] (2004). Technical Analysis of the August 14, 2003, Blackout: What Happened, Why, and What Did We Learn? New York, North American Electric Reliability Council.

[16] (2004). Intrim Report on the August 14,2003 Blackout. New York.

[17] Wan Ki Min., M. H. Y. (1995). High performance control of harmonic instability from HVDC link system. Energy Management and Power Delivery, 1995. Proceedings of EMPD '95., 1995 International Conference on ,. vol.2,: pp.726-731 vol.722,

[18] Rahman, H., Khan, B.H., (2004). Enhanced power transfer by simultaneous transmission of AC-DC: A new facts concept. Power Electronics, Machines and Drives, 2004. (PEMD 2004). Second International Conference on vol.1, : pp. 186- 191

[19] H.A.Avilar (2008). Study of Supplementary controls for embedded HVDC Links in AC Power Systems. Goteborg, Chalmers University of Technology. 
[20] Apostolov, A., Vandiver, B. , (2008). Ensuring the Correct Operation of Distance Relays Under Dynamic System Conditions. Protective Relay Engineers, 2008 61st Annual Conference for pp.72-77,.

[21] Apostolov, A. P. (2005). Distance relays operation during the August 2003 North American Blackout and methods for improvement. Power Tech, 2005 IEEE Russia pp.1-6,

[22] Richards, S., Tholomier,D., Improving the Performance of Distance Protection during Wide Area Disturbances.

[23] Carlsson, L. (2005). A 'firewall' against disturbances in high-voltage grids.

[24] Pan, J. P., Nuqui,R., Berggren,B., Thorburn,S., Jacobson,B., (2009). The balance of power. Transmission and distribution.

[25] Bahrman, M. P., Johnson,B.K., (2007). The ABCs of HVDC Transmission Technology. IEEE Power \& Energy Magazine 5: pp.32-44.

[26] Setreus, J., Bertling,L., (2008). Introduction to HVDC Technology for Reliable Electrical Power Systems. Probabilistic Methods Applied to Power Systems, 2008. PMAPS '08. Proceedings of the 10th International Conference on pp.1-8.

[27] Andres, J. M., Dorn,J., Retzmann,D., Soeranger,D., Zenkner,A., (2007). Prospects of VSC Converters for Transmission System Enhancement. Europe Power Grid. Madrid, Spain.

[28] Povh, D., Retzmann,D., Teltsch,E., Kerin,U., Mihalic,R., (2006). Advantages of Large AC/DC System Interconnection.

[29] Bahrman, M. P., P.E., HVDC Transmission Overiew.

[30] Beck, G., Breuer,W., Povh,D., Retzmann,D., Teltsch,E., (2006). Use of FACTS and HVDC for Power System Inteconnection and Grid Enhancement.

[31] Retzmann, D., Uecker,K., (2007). Benefits of HVDC \& FACTS for Sustainability and Security of Power Supply. Power Africa Conference and Exposition. Johannesburg, South Africa.

[32] Kreusel, J., Retzmann,D., (2008). Integrated AC/DC Transmission Systems - Benefits of Power Electronics for Security and Sustainability of Power Supply.

[33] Breuer, W., Povh,D., Retzmann,D., Urbanke,C., Weinhold,M., (2007). Prospects of Smart Grid Technologies for a Sustainable and Secure Power Supply. The 20th World Energy Congress \& Exhibition. Rome, Italy.

[34] Andres, J. M. P., Muhlenkamp,M., Retzmann,D., Walz,R., (2006). Prospects for HVDC - Getting more Power out of the Grid.

[35] Ramaswami, V., Retzmann,D., Uecker,K., (2007). Prospects of Bulk Power EHV and UHV Transmission. New Technologies in Transmission, Distribution, Load Dispatch \& Communication. New Delhi, India.

[36] Carlsson, L. (2006). HVDC - A firewall against disturbances in HV grids.

[37] Dandachi, N., Siddiqui,H., Masood,A., Uddin,E., Interconnection Control and Operational Challenges with HVDC Link.

[38] Kuehn, W. (2010). Real-time method to prevent voltage collapse and power instability of HVDC systems. Innovative Smart Grid Technologies Conference Europe (ISGT Europe), 2010 IEEE PES ,: pp.1-8.

[39] Zhang, L. D., Harnefors,L., Rey,P., (2007). Power System Reliability and Transfer Capabilty Improvement by VSCHVDC. Security and Reliability of Electric Power Systems, CIGRE Regional Meeting. Tallinn, Estonia.

[40] Basu, K. P. (2009). Stability enhancement of power system by controlling HVDC power flow through the same AC transmission line. Industrial Electronics \& Applications, 2009. ISIEA 2009. IEEE Symposium on. 2: pp.663-668,

[41] Lee, R. L., Melvold, D.J., Szumlas, D.J., Le, L.M., Finley, A.T., Martin, D.E., Wong, W.K., Dickmander, D.L., (1993). "Potential DC system support to enhance AC system performance in the Western United States." Power Systems, IEEE Transactions on vol.8, no.1: pp.264-274.

[42] Corsi, S., Danelli, A., Pozzi, M., (2002). Emergency-stability controls through HVDC links. Power Engineering Society Summer Meeting, 2002 IEEE ,. vol.2,: pp.774-779

[43] Arro, T., Silavwe,O., (2007). Coupling of Transients in HVDC Lines to Adjacent HVAC Line and its Impact on the AC Line Protection. Department of Energy \& Environment. Göteborg, Chalmers University Of Technology. Master of Science: 121.

[44] Du, C. Q. (2003). The control of VSC-HVDC and its use for large industrial power systems. Electrical Engineering. Goteborg, Chalmers University of Technology. Ph.D.

[45] Paulinder, J. (2003). Operation and control of HVDC links embedded in AC systems. Electrical Engineering. Cotebrog, Chalmers University of Technology. Ph.D.

[46] Zhang, X.-P., Yao, L., Chong, B., Sasse, C., Godfrey, K.R., (2005). FACTS and HVDC technologies for the development of future power systems. Future Power Systems, 2005 International Conference on ,.

[47] Breuer, W., Retzmann,D., Uecker,K., (2010). Highly Efficient Solutions for Smart and Bulk Power Transmission of 'Green Energy'. 21th World Energy Congress. Montreal, Canada.

[48] Breuer, W., Hartmann,N., Povh,D., Retzmann,D., Teltsch,E., Application of HVDC for Large Power System Interconnections.

[49] Abdlrahem, A.A.; Sherwali, H.H.; "Modelling of numerical distance relays using MATLAB," Industrial Electronics \& Applications, 2009. ISIEA 2009. IEEE Symposium on, vol.1, no., pp.389-393, 4-6 Oct. 2009.

[50] Luo, L.F., Li, Y., Nakamura, K., Krost, G., Li, J., Xu, J.L., Liu, F.S., 2008. Harmonic Characteristics of New HVDC Transmission System Based on New Converter Transformer.

[51] Johns, A.T.; Aggarwal, R.K.; , "Performance of high-speed distance relays with particular reference to travellingwave effects, "Electrical Engineers, Proceedings of the Institution of , vol.124, no.7, pp.639-646, July 1977

[52] Pradeep K.G. Tarlchan S. S.; Gregory J. F; , "Current Transformer Dimensioning for Numerical Protection Relays," Power Delivery, IEEE Transactions on, vol.22, no.1, pp.108-115, Jan. 2007 
[53] Li-Cheng Wu; Chih-Wen Liu; Ching-Shan Chen;, "Modeling and testing of a digital distance relay MATLAB/SIMULINK," Power Symposium, 2005. Proceedings of the 37th Annual North American, vol., no., pp. 253- 259, 23-25 Oct. 2005

[54] Casoria, S., Thyristor-Based HVDC Transmission System.

[55] ABB The HVDC Transmission Quebec-New England. The first large scale mutitiminal HVDC transmission in the world.

[56] ABB The Quebec-New England transmission.

[57] Ulleryd, J., Ming Ye, Moreau, G., (1998). Fundamental frequency coupling between HVAC and HVDC lines in the Quebec-New England multiterminal system-comparison between field measurements and EMTDC simulations,. Power System Technology, 1998. Proceedings. POWERCON '98. 1998 International Conference on , . 1: pp.498502

[58] Morin, G., Bui, L.X., Casoria, S., Reeve, J. , (1993). "Modeling of the Hydro-Quebec-New England HVDC system and digital controls with EMTP." Power Delivery, IEEE Transactions on vol.8, no.2,: pp.559-566, .

[59] Lemay, J. (1992). "Hydro-Quebec's High-Voltage Interconnections." Power Engineering Review, IEEE vol.12, no.6,: pp.7, .

[60] Bui, L. X., Morin, G. , (1996). Some experiences in power system simulation using electromagnetic transient programs,. Electrical and Computer Engineering, 1996. Canadian Conference on ,. vol.2,: pp.647-650.

[61] Yao,L.X., Yao,J.X., An,Y., 2005. Fault Location Simulation For High Voltage Power Transmission Line Based on Matlab/Simulink.

[62] ALSTOM T\&D Protection \& Control Ltd, 1987. Protective Relays Application Guide.

\section{BIOGRAPHY OF AUTHOR}

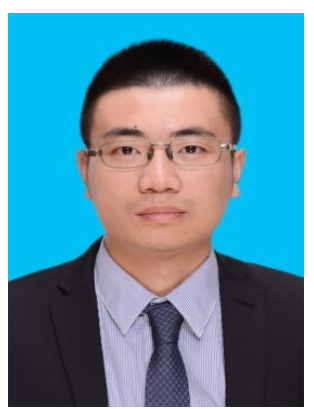

Dr. Hualei Wang received his Ph.D. Degree from University of Bath, UK in 2015. His research interests include HVDC and distance protection. Currently he is working in State Grid Qingdao Electricity Supply Company in the Department of Distribution networks and automatic. 